\title{
A confirmatory factor analytic study of an authentic leadership measure in Nigeria
}

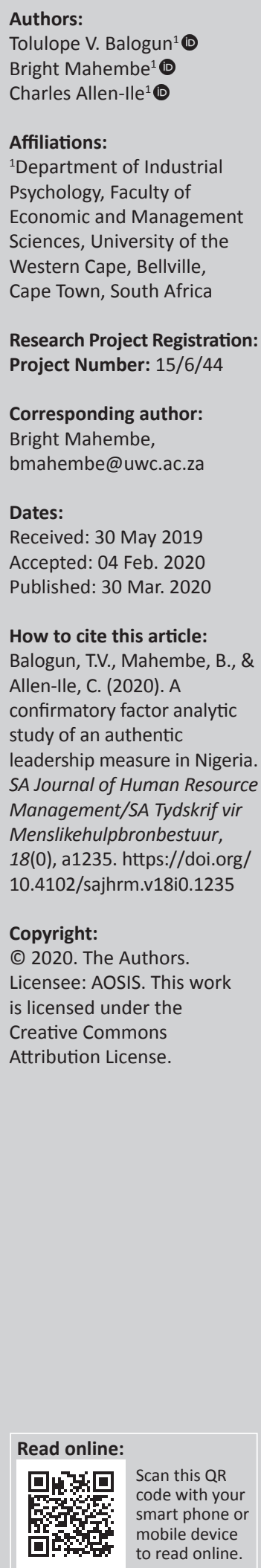

Orientation: Authentic leadership has been identified as one of the competencies for effective leaders.

Research purpose: The primary goal of the present study was to test, on a Nigerian sample, the psychometric properties of the Authentic Leadership Inventory (ALI) developed by Neider and Schriesheim.

Motivation for the study: Various instruments have been developed to measure authentic leadership, with the ALI being one of the widely used questionnaires. There is a need to assess the reliability and construct validity of the ALI on a Nigerian sample owing to paucity of studies on its psychometric properties in this setting.

Research approach/design and method: A non-probability sample consisting of 213 bank employees working in Nigeria was studied. The ALI was used to measure authentic leadership, and its reliability was evaluated using SPSS, while construct validity was assessed through confirmatory factory analyses in the Linear Structural Relations (LISREL) programme.

Main findings: Moderate levels of reliability were found for the subscales of the ALI. Reasonable model fit with the data was found for the first- and second-order as well as the bi-factor and single-factor measurement models through confirmatory factor analyses (CFA).

Practical/managerial implications: Although the ALI demonstrated reasonable model fit for the CFA models tested in this study, the reliability coefficients of the relational transparency and internalised moral perspective subscales were below the 0.70 threshold. In addition, the discriminant validity of the self-awareness and the internalised moral perspective subscales was not achieved.

Contribution/value-add: The study promotes the use of reliable and valid instruments in Nigeria by confirming the psychometric properties of the ALI.

Keywords: authentic leadership; internal consistency; goodness-of-fit; construct validity; bi-factor.

\section{Introduction}

The expression of an authentic self is a fundamental requirement in leadership (Covelli \& Mason, 2017; Goffee \& Jones, 2005). Authentic leadership is a challenge that most organisations are faced with. It is generally defined as a leader's ability to display high levels of self-awareness, relational transparency, internalised moral perspective and balanced processing (Johnson, 2019; Kotzé \& Nel, 2019; Luthans \& Avolio, 2003). Self-awareness alludes to the leader's awareness of his or her own strengths and weaknesses; relational transparency indicates a leader's open expression of his or her thoughts and feelings while being guided by his or her internalised moral perspective in the form of values and self-regulation in decision-making. The decisions are made after an in-depth and balanced processing of all the facts at the leader's disposal - through balanced processing (Kotzé \& Nel, 2019).

There is an anticipated authenticity that every follower demands of a leader - to be real, trustworthy, sincere, dependable, genuine, just and honest. Luthans and Avolio (2003) referred to authenticity as the congruence between what one says, is and does, while Avolio, Gardner, Walumbwa, Luthans and May (2004, p. 802) citing McCain and Salter (2004) referred to the importance of being authentic as learning to love honesty and upholding of justice, 'not just for their effect on personal circumstances' but for their impact on humanity and on the world at large. When authentic characteristics are demonstrated by the leader, followers are motivated to adhere to or obey the leader's rules and initiate more commitment towards the organisation. Goffee and Jones (2005) 
and Datta (2015) furthermore proposed that only subordinates or followers can attest that a leader is authentic. It thus implies that leaders cannot classify themselves as authentic but can only be observed as authentic by other people.

Authentic leaders advance factual lives, and their followers are motivated to do the same. Authentic leaders actively pass to their followers, a desire for fulfilment, a drive for success and psychological capacities needed for high-level performance and commitment (Johnson, 2019; Kotzé \& Nel, 2019). Citing Gardner and Schermerhorn, Avolio et al. (2004) noted that the duty of an authentic leader is to cultivate optimism in followers. Avolio (1999) clarified that authentic leaders act in accordance with their intrinsic personal values and convictions. They do this to build credibility and win the respect and trust of followers by encouraging diverse viewpoints and building networks of collaborative relationships such that they lead in a manner that followers recognise as authentic. These actions exhibited by an authentic leader will subsequently propel the employees or the followers to act in a similarly authentic manner, which consequently will become a basis to create a stable organisational culture.

Although the authentic leadership construct is not a new theory, there are still few divergent opinions about what authentic leadership really portrays and how it stands out from other effective leadership styles like transformational leadership. It has even been argued that conceptually, authentic leadership intersects with some other forms of positive leadership behaviours (Avolio \& Gardner, 2005). However, in spite of the dissenting opinions that persist, most scholars have noted and accepted authentic leadership and its four dimensions as a distinct, separate leadership construct (Gardner, Cogliser, Davis, \& Dickens, 2011; Johnson, 2019; Klenke, 2007; Kotzé \& Nel, 2019; Yammarino, Dionne, Schriesheim, \& Dansereau, 2008), with some researchers engaged in refining its theoretical models (Gardner, Avolio, Luthans, May, \& Walumbwa, 2005; Ilies, Morgeson, \& Nahrgang, 2005), some in redeveloping its measures of assessment (Luthans, Avolio, Avey, \& Norman, 2007; Neider \& Schriesheim, 2011; Walumbwa, Avolio, Gardner, Wernsing, \& Peterson, 2008) and others preoccupied with testing for antecedents, consequences, mediators and moderators (Alok, 2014; Gardner et al., 2011). Furthermore, Avolio and Gardner (2005) stated that authentic leadership behaviours form the basis and act as a solid foundation on which sincere transformational leadership behaviours can be constructed. Therefore, in spite of the similarities between authentic leadership and transformational leadership, and the expectations of followers to see ideal role models and inspirers in their leaders who adopt these leadership behaviours, there are still distinct, well-defined differences that distinguish them.

Walumbwa et al. (2008) have conceptualised the authentic leadership construct as a leadership behaviour that is typified by robust self-awareness, uncommon relational transparency, exceptional internalised moral perspective and unequivocal balanced information processing for ethical decision-making. Although the authentic leadership theory developed by Luthans and Avolio (2003) is priceless, as it promoted scholarly attention and provided a significant basis for the leadership construct, several authors (Avolio \& Gardner, 2005; Gardner et al., 2005; Ilies et al., 2005; Walumbwa et al., 2008) have built on their work and created a better understanding of the construct, of which Walumbwa et al. (2008) had endeavoured to produce the most generally accepted definition of authentic leadership within the literature (Banks, McCauley, Gardner, \& Guler, 2016).

As a sequel to the Authentic Leadership Questionnaire (ALQ) by Walumbwa et al. (2008), the Authentic Leadership Inventory (ALI) was developed by Neider and Schriesheim (2011). The authors developed the ALI on the basis of the four-dimensional instrument, which was operationalised and conceptualised by Walumbwa et al. (2008). The authors developed the ALI because of some of their misgivings about the ALQ (Walumbwa et al., 2008) with regard to its reliability and validity (Van Der Vaart, Stander, \& Rothmann, 2015).

Subsequently, in spite of the efforts that have been made in the Western world to clarify the authentic leadership construct and to present a most appropriate reliable scale to assess the construct, very little work has been carried out in the African context around the reliability and validity of the ALI. Two South African studies, Van Der Vaart et al. (2015) and Stander, De Beer and Stander (2015), established that the ALI shows an acceptable fit, with the majority of the variables exhibiting satisfactory reliability estimates between 0.60 and 0.93 . It is against these underpinning discussions that this study sought to test the psychometric properties of the ALI in a Nigerian sample. This study therefore tests the reliability and construct validity of the ALI so as to determine whether the original factor structure developed in the United States by Neider and Schriesheim (2011) can be confirmed on a Nigerian sample.

\section{Aim of the study}

The main objective of the study was to ascertain the reliability and construct validity of the ALI developed in the United States by Neider and Schriesheim (2011) on a Nigerian sample. The specific objectives of the study were to confirm the:

- reliability of the ALI by computing the Cronbach's alpha reliability coefficients for each of the subscales

- construct validity of the ALI by testing the first- and second-order model goodness-of-fit using confirmatory factor analyses (CFA)

- discriminant validity of the ALI.

\section{Contribution to the field}

Authentic leadership has been found to significantly influence followers' trust in the leader and the development of positive emotions in the workplace (Agote, Aramburu, \& Lines, 2016) as well as help foster creativity and innovativeness (Müceldili, Turan, \& Erdil, 2013). It also promotes team commitment and the development of both psychological capital and psychological climate (Munyaka, Boshoff, Pietersen, \& Snelgar, 2017). The importance of authentic leadership necessitated the need to ascertain the reliability and validity of its measurement using the ALI. Therefore, the 
major contribution of the current study is that it adds to the board of knowledge on the psychometric properties of the ALI in the Nigerian context.

\section{Authentic leadership theory}

Harter dated back authenticity as a concept to the ancient Greek philosophers who described the term to mean 'Know thyself' and 'To thine own self be true' (Avolio et al., 2004), although Ilies et al. (2005) differed by indicating that authenticity far exceeds being true to oneself. Harter (2002, p. 382) classified authenticity as 'owning one's personal experiences, be they thoughts, emotions, needs, preferences or beliefs, processes captured by the injunction to know oneself'. Using the theory and concept of authenticity, Luthans and Avolio (2003) described authentic leadership as a process in which the core components are 'self-awareness and self-regulated positive behaviours on the part of leaders and associates, fostering positive self-development'.

\section{Authentic leaders are (Avolio et al., 2004):}

[T] hose individuals who are deeply aware of how they think and behave and are perceived by others as being aware of their own and others' values/moral perspective, knowledge, and strengths; aware of the context in which they operate; and who are confident, hopeful, optimistic, resilient, and high on moral character. (p. 802)

Kark and Shamir (2013) proposed that authentic leaders have what it takes to boost and motivate their followers such that they can be much more dedicated, enthusiastic, engrossed and engaged in their work roles (Avolio et al., 2004).

Northhouse (2015) proposed three models of authentic leadership based on the previous work of Avolio and Gardner (2005), Eagly (2005), Shamir and Eilam (2005) and Walumbwa et al. (2008). These models are the intrapersonal, developmental and interpersonal models. The intrapersonal authentic leadership model is rooted on self-concept and how selfconcept relates to the leader's actions (Shamir \& Eilam, 2005). These authors stated that authentic leadership is characterised by genuine leadership, conviction, originality and action based on values. Secondly, Avolio and Gardner (2005) and Walumbwa et al. (2008) described authentic leadership as a developmental style of leadership. They proposed that leadership can be cultivated, nurtured and developed over a lifetime and can be triggered by major life events. These authors support their argument on the developmental model of four components: self-awareness, internalised moral perspective, balanced processing and relational transparency. Thirdly, the interpersonal definition of authentic leadership by Eagly (2005) noted that leadership is created by a joint effort between the leader and the follower. Leaders create the change they desire when they amend their message in accordance to their followers' values, while followers also realise intended outcomes when they identify with the leader's values.

Furthermore, George (2003), George, Sims, McLean and Mayer (2007) and Terry (1993) introduced two practical approaches to authentic leadership. Terry's approach was an action/practice-centred model, which suggests that leaders should endeavour to do what is right. It lays emphasis on the action of the leader or leadership in a particular situation. The author developed an Authentic Action Wheel to assist leaders with their problems by detecting the problem on the diagnostic wheel and then tactically selecting a suitable response to address the problem. On the contrary, George (2003) and George and Sims (2007) developed a leader characteristic model, which suggests that leaders have genuine desire to serve others. The authors' approach of authentic leadership is characterised by the following: understanding of purpose, strong values, trusting relationships, self-discipline and actions taken from the heart.

For the purpose of this study, however, authentic leadership is conceptualised on the developmental model, which is based on the four-component model of authentic leadership modified from the works of Gardner et al. (2005), Ilies et al. (2005) and Luthans and Avolio (2003). Authentic leadership is therefore defined as "a pattern of leader behaviour that draws upon and promotes both positive psychological capacities and a positive ethical climate, to foster greater selfawareness, an internalised moral perspective, balanced processing of information, and relational transparency on the part of leaders working with followers, fostering positive self-development" (Walumbwa et al., 2008, p. 94).

\section{Self-awareness}

Self-awareness is a never-ending process of personal examination and re-evaluation by leaders of their own competences, abilities, strengths, weaknesses, limitations, beliefs and moral principles. They are fully aware of the impact they make on people, acknowledge those around them and fully understand how people perceive them.

\section{Relational transparency}

Relational transparency refers to the openness exhibited by the leader towards his or her followers. The leader properly balances his or her own thoughts, beliefs and principles with the right emotions. He or she promotes a level of honesty and sincerity with others, which encourages others to willingly reciprocate such positive attributes (Gardner et al., 2005). This kind of relationship fosters trust between the followers and the leadership.

\section{Balanced processing}

The leader solicits sufficient opinions, ideas and suggestions from the followers and objectively analyses them before reaching a conclusion. Such leaders often solicit viewpoints that oppose their deeply held standpoint (Gardner et al., 2005).

\section{Internalised moral perspective}

This is an 'internalized and integrated form of self-regulation' (Ryan \& Deci, 2003). It is the degree to which the leader sets a high standard for moral and ethical conduct. This form of self-regulation is guided by positive ethical foundation, 
which is adhered to by the leader in spite of conflicting societal pressures or organisational norms. This is expressed in decision-making and behaviour, which is consistent with these internalised values (Gardner et al., 2005).

\section{Authentic leadership measurement}

Most popular among the authentic leadership assessment scales are the two multidimensional scales: ALI by Neider and Schriesheim (2011) and the ALQ by Walumbwa et al. (2008). Both the ALI and ALQ measure four similar theoretically related components, such as self-awareness, relational transparency, internalised moral perspective and balanced processing. Previous studies have utilised the ALQ in an African context. The ALQ was administered in Kenya on working adults from 11 different American multinational companies (Walumbwa et al., 2008); Namibia with employees from a state-owned enterprise (Amunkete \& Rothmann, 2015); South Africa from a private sector healthcare organisation (Du Plessis, 2014); and two other manufacturing organisations (Munyaka et al., 2017; Roux, 2010).

Walumbwa et al. (2008) confirmed both the convergent and discriminant validity of the ALQ and reported a coefficient alpha of 0.93 for the ALQ. The authors reported an item factor loading ranging between 0.62 and 0.93 in the initial study: with self-awareness of 0.92 , transparency of 0.87 , moral/ ethical perspective of 0.76 and balanced processing of 0.81 (Walumbwa et al., 2008). Several other authors, including Alok and Israel (2012), Clapp-Smith, Vogelgesang and Avey (2009), Walumbwa, Avolio and Hartnell (2010), Walumbwa, Wang, Wang, Schaubroeck and Avolio (2010), Wang and Hsieh (2013) and Wang, Sui, Luthans, Wang and Wu (2014), have validated the reliability of the ALQ. The fourdimensional structure of authentic leadership was validated by the results by Walumbwa et al. (2008) as well as Roux (2010), which demonstrated an acceptable fit.

The ALI was developed by Neider and Schriesheim (2011) in the United States on the basis of the four-dimensional instrument, which was operationalised and conceptualised by Walumbwa et al. (2008). The authors developed the ALI because of the scepticisms raised regarding the original ALQ (Walumbwa et al., 2008). They asserted that 'the instrument was not available for commercial use - future use for research purposes was going to become challenging', the 'content analysis was very subjective' and that Walumbwa et al. (2008) found that a 'second-order factor model fitted the data significantly better than a first-order factor model' (Van Der Vaart et al., 2015). Relational transparency was measured by three items; self-awareness by three items; internalised moral perspective by four items; and balanced processing by four items. The authors administered the ALI in America within three different groups. The results of the analyses from their second study proved that construct, content and discriminant validity as well as internal consistency were supported.

In a South African quantitative cross-sectional study comprising of 244 employees that worked in a South African mining company, Van Der Vaart et al. (2015) also established that the ALI shows an acceptable fit, with the majority of the variables exhibiting satisfactory reliability estimates between 0.60 and 0.93. The authors, however, noted that the balanced processing component of the ALI was below acceptable reliability estimates (0.43) - 'My leader uses his/her core beliefs to make decisions' had the lowest loading on authentic leadership $(\beta=0.48, p<0.001)$ and therefore needed additional work and improvement. Similar to the findings of Neider and Schriesheim (2011), items 1 and 6 were removed from the analyses. In another South African study, Stander et al. (2015) indicated the reliability ( $\alpha=0.93$ ) of the ALI as was the case in the studies of Neider and Schriesheim (2011) and Stander et al. (2015). Previous studies found acceptable reliabilities with Cronbach's alpha coefficients ranging between 0.74 and 0.90 (Men \& Stacks, 2014; Neider \& Schriesheim, 2011).

\section{The present study}

This study, therefore, assessed the reliability and construct validity of the ALI on a sample of employees in the Nigerian banking sector.

\section{Research design Research approach}

To realise the objectives of the study, a quantitative research design was used through structural equation modelling (SEM).

\section{Research method}

\section{Sample}

The respondents who participated in the study were bank employees with at least 12 years of schooling and proficiency in English. The respondents had a direct supervisor or manager to whom they reported as the survey required respondents to evaluate their leader's authenticity. The sample consisted of 213 bank employees comprising female $(46.8 \%)$ and male (53.2\%) employees. The majority (47.4\%) fell in the 31-40 age category. The ethnic distribution in the sample was highly skewed with $96.7 \%$ black people, $0.55 \%$ mixed race, $2.2 \%$ white people and $0.55 \%$ Asians. The majority (98.1\%) of the respondents had a matric qualification as their highest level of education.

\section{Measuring instrument}

The composite questionnaire composed of a biographical questionnaire and the ALI developed by Neider and Schriesheim (2011). The respondents were asked to rate their leader's authenticity and indicate demographic variables such as their reporting unit, tenure in the bank, age of respondent, gender, ethnicity, highest educational qualification obtained and position held in their organisation.

Authentic leadership was measured using the original ALI (Neider \& Schriesheim, 2011). The ALI measures four theoretically related components, such as self-awareness (four items), for example, 'My leader is clearly aware of the impact he or she has on others'; relational transparency 
(four items), for example, 'My leader admits mistakes when they occur'; internalised moral perspective (four items), for example, 'My leader uses his or her core beliefs to makes decisions'; and balanced processing (four items), for example, 'My leader carefully listens to alternative perspectives before reaching a conclusion'. Respondents were asked to rate their current supervisor/manager on a 5-point Likert scale, ranging from 1 = disagree strongly to $5=$ agree strongly.

\section{Research procedure and ethical considerations}

Initially, the researcher developed a Google Form where the ALI was included. This form was then forwarded to recipients through a snowballing sampling method. This course of action was taken so as to have access to more respondents and to allow the respondents easy accessibility to the questionnaire because many of the bank employees have Internet access. However, this route was discarded because of a very low feedback and turnaround rate - about 10 questionnaires were completed in a space of about 6 weeks. As a result, the questionnaires were then printed and copies were distributed to participants.

Permission to conduct the present study was obtained from all necessary authorities prior to the commencement of the study. Permission from the university's research ethics committee was received. Informed consent was obtained from the respondents before they completed the questionnaires. The respondents were informed of the purpose of the research and assured of the anonymity and confidentiality of the data obtained. Their voluntary participation in the study was emphasised.

\section{Statistical analysis}

The analyses utilised in this study were the following: (1) item analysis, to determine the reliability of the scales; (2) exploratory factor analysis (EFA), to ascertain scale dimensionality; and (3) and SEM, to determine the construct validity of the ALI.

\section{Structural equation modelling}

Structural equation modelling is a technique that brings to the fore the nature of the hypothesised covariate relationships between the observed and the latent variables, as indicated in the measurement and structural models (Diamantopoulos \& Siguaw, 2000). The measurement model describes the quality of the relationships between the manifest or observed variables and the latent variables while the structural model describes the nature of the relationships between the latent variables themselves (Diamantopoulos \& Siguaw, 2000).

\section{Confirmatory factor analysis}

LISREL 8.80 (Jöreskog \& Sörbom, 2006b) was used to test the uni-dimensional, first- and second-order as well as the bi-factor CFA on the ALI to determine the fit of the models. Robust maximum likelihood (RML) estimation was used as the default parameter estimation method in the case of a lack of multivariate normality in the data (Jöreskog \& Sörbom, 1996).

\section{The evaluation of the Authentic Leadership Inventory first-order model}

The evaluation of the ALI CFA models was based on the following indices: the root mean square error of approximation (RMSEA); root mean square residual (RMR); the goodnessof-fit index (GFI); normed fit index (NFI); non-normed fit index (NNFI); comparative fit index (CFI); incremental fit index (IFI); and the relative fit index (RFI).

The RMSEA is generally regarded as one of the most informative fit indices, as it tests for the closeness of fit in the null hypothesis (Diamantopoulos \& Siguaw, 2000; Schumacker \& Lomax, 2016). Root mean square error of approximation values below 0.05 are suggestive of good fit, those between 0.05 and under 0.08 suggest reasonable fit, values between 0.08 and 0.10 denote mediocre fit and values $>0.10$ indicate poor fit (Diamantopoulos \& Siguaw, 2000).

The RMR presents the average value of the difference between the sample covariance (variance) and a fitted (model-implied) covariance (variance). In other words, it is a summary measure of fitted residuals (Diamantopoulos \& Siguaw, 2000; Hair et al., 2010).

The GFI depicts how closely the model comes to perfectly reproducing the observed covariance matrix. The GFI is usually recommended as the most reliable measure of the model fit (Diamantopoulos \& Siguaw, 2000). The values of the GFI greater than 0.90 are usually considered as indicating acceptable fit (Diamantopoulos \& Siguaw, 2000).

For model comparative purposes, the RFI, IFI, the BentlerBonett NNFI, the Bentler-Bonett NFI and the CFI (Diamantopoulos \& Siguaw, 2000; Schumacker \& Lomax, 2016) are recommended. Values greater than 0.90 are usually regarded as acceptable (Diamantopoulos \& Siguaw, 2000).

\section{Results \\ Missing values}

Missing values were addressed through the use of multiple imputations (Jöreskog \& Sörbom, 2006a). This technique allowed the missing values to be substituted with values derived from averages with the aid of simulation (Jöreskog \& Sörbom, 2006a; Rubin, 2004). The final sample size was 213; no cases were deleted.

\section{Item analysis}

Using the SPSS version 25 (SPSS Inc., 2017), item and dimensional analyses were performed on the items of the ALI. Two of the internal consistency coefficients of the ALI missed the acceptable cut-off level $(\alpha>0.70)$ (Nunnally \& Bernstein, 1994) (Table 1). The four ALI subscales were found to be uni-dimensional, and the variance explained by each of the factors was generally above $50 \%$ (Table 1) with the 
exception of the internalised moral perspective subscale. The correlations among the four latent ALI dimensions are shown in Table 2. The correlations are within reasonable limits and not above 0.90 , as this could indicate multicollinearity (Pallant, 2016; Tabachnick \& Fidell, 2013).

\section{Evaluating the fit of the measurement model}

Confirmatory factor analysis was carried out on the items of the ALI through LISREL 8.80 (Du Toit, Du Toit, Mels, \& Cheng, 2008; Jöreskog \& Sörbom, 2006a) to evaluate the construct validity of the measurement models. The ALI measurement model was considered as an exogenous variable; list-wise deletion and the RML estimation method were utilised to produce the required estimates. The normalised data set was used for subsequent analyses.

\section{Goodness-of-fit of the first-order, second-order, bi-factor and single-factor measurement models}

Table 3 shows that the three authentic leadership measurement models tested in the present study show similar levels of fit with regard to the CFI, RMSEA and SRMR. Both first-order and second-order measurement models indicate reasonable model fit. In terms of the CFI, the first-order and secondorder measurement models show a similar value of 0.97 , while the bi-factor model CFI is slightly higher with a value of 0.98 . In terms of the SRMR, the bi-factor model marginally missed the accepted 0.05 cut-off level, compared to the other models. The GFI values for all the models with the exception of the bi-factor model missed the 0.90 cut-off. An overall look at the fit indices of the three models indicates that the bi-factor model fit indices are generally within the acceptable

TABLE 1: Reliability and exploratory factor analysis output for the Authentic Leadership Inventory dimensions.

\begin{tabular}{lcccc}
\hline Scale & $\begin{array}{c}\text { Number of Cronbach's } \\
\text { items }\end{array}$ & $\begin{array}{c}\text { Factor } \\
\text { alpha }\end{array}$ & $\begin{array}{c}\text { \% Variance } \\
\text { loadings } \\
\text { explained }\end{array}$ \\
\hline 1. Self-awareness & 4 & 0.71 & $0.55-0.69$ & 54.1 \\
2. Relational transparency & 4 & 0.66 & $0.50-0.68$ & 50.9 \\
3. Internalised moral perspective & 4 & 0.58 & $0.34-0.64$ & 44.4 \\
4. Balanced processing & 4 & 0.75 & $0.58-0.71$ & 57 \\
\hline Total scale & $\mathbf{1 6}$ & $\mathbf{0 . 9 0}$ & - & - \\
\hline
\end{tabular}

TABLE 2: Inter-correlations between latent Authentic Leadership Inventory dimensions, average variance extracted and shared variance estimates $(N=213)$. \begin{tabular}{lllllll}
\hline Subscales & $M$ & SD & 1 & 2 & 3 & 4
\end{tabular}

\begin{tabular}{lllllll}
\hline 1. Self-awareness & 14.87 & 2.82 & $\mathbf{0 . 3 9}$ & 0.52 & 0.36 & 0.46
\end{tabular}

$\begin{array}{llllllll}\text { 2. Relational transparency } & 14.98 & 2.67 & 0.72 & \mathbf{0 . 3 4} & 0.49 & 0.56\end{array}$

$\begin{array}{lllllll}\text { 3. Internalised moral perspective } & 14.92 & 2.57 & 0.60 & 0.70 & \mathbf{0 . 4 2} & 0.49\end{array}$

$\begin{array}{lllllll}\text { 4. Balanced processing } & 14.47 & 3.13 & 0.68 & 0.75 & 0.70 & \mathbf{0 . 2 7}\end{array}$

Note: $N=213$; the bold values represent the diagonal (the AVE estimates). The correlates are below the diagonal, whilst the squared correlates are above the diagonal.

$\mathrm{AVE}$, average variance extracted; SD, standard deviation; $M$, Mean

TABLE 3: Goodness-of-fit indices obtained for the Authentic Leadership Inventory first-order and single-factor measurement models.

\begin{tabular}{lcccccccc}
\hline Model & RMSEA & SRMR & GFI & NFI & NNFI & CFI & IFI & RFI \\
\hline First-order CFA & 0.067 & 0.062 & 0.86 & 0.94 & 0.97 & 0.97 & 0.97 & 0.93 \\
Second-order CFA & 0.0666 & 0.063 & 0.86 & 0.94 & 0.97 & 0.97 & 0.97 & 0.93 \\
Bi-factor model & 0.0669 & 0.0508 & 0.99 & 0.95 & 0.97 & 0.98 & 0.98 & 0.93 \\
\hline
\end{tabular}

CFA, confirmatory factor analyses; RMSEA, root mean square error of approximation; SRMR, standardised root mean residual; GFI, goodness-of-fit; NFI, normed fit index; NNFI, nonnormed fit index; $\mathrm{CFI}$, comparative fit index; IFI, incremental fit index; RFI, relative fit index. fit cut-off levels, compared to the first-order, second-order and single-factor models. This lends some support to the possibility that the ALI measures a general construct (i.e. authentic leadership).

Neider and Schriesheim (2011) argued that the four authentic leadership dimensions-self-awareness, relational transparency, balanced processing and internalised and moral perspective have a higher order factor, namely, authentic leadership (Neider \& Schriesheim, 2011). The second-order model explains that authentic leadership is a higher order factor that explains why the four authentic leadership dimensions are correlated. In the second-order factor model, there is no direct relationship between the target authentic leadership trait and the items. In fact, the four authentic leadership dimensions indicate an indirect effect (Nel \& Van Zyl, 2015), thereby mediating upon the relationship. According to Nel and Van Zyl (2015), the presence of a higher order factor can be determined by using a bi-factor model, which enables the researcher to determine 'the degree to which items reflect a common trait' and 'the degree to which they reflect sub-traits' (i.e. observed variables of the ALI) (Nel \& Van Zyl, 2015, p. 5).

Table 4 shows that six of the 16 items have higher loadings on the general factor, compared to the group factors, while three items have similar loadings. This indicates that although the influence of the general factor is not dominant, it still has some influence on the group factors.

The completely standardised factor loadings are shown in Table 4 . The values shown in the completely standardised solution loading matrix indicate the average change expressed in standard deviations in the item associated with one standard deviation change in the latent variable (Diamantopoulos \& Siguaw, 2000). The factor loadings of the items are generally significant $(>0.30)$ with the exception of the item Auth7.

\section{Parameter estimates}

The unstandardised Gamma matrix shows the strength of the relationship and the influence of the exogenous latent

TABLE 4: Standardised factor loadings for the bi-factor (Authentic Leadership Inventory, $N=213$ )

\begin{tabular}{lccccc}
\hline Item & $\begin{array}{c}\text { General } \\
\text { factor }\end{array}$ & $\begin{array}{c}\text { Self- } \\
\text { awareness }\end{array}$ & $\begin{array}{c}\text { Relational } \\
\text { transparency }\end{array}$ & $\begin{array}{c}\text { Balanced } \\
\text { processing }\end{array}$ & $\begin{array}{c}\text { Internalised moral } \\
\text { perspective }\end{array}$ \\
\hline Auth1 & 0.51 & 0.57 & - & - & - \\
Auth2 & 0.52 & - & 0.54 & - & - \\
Auth3 & 0.57 & - & - & - & 0.56 \\
Auth4 & 0.66 & - & - & 0.58 & - \\
Auth5 & 0.66 & 0.62 & - & - & - \\
Auth6 & 0.70 & - & 0.63 & - & - \\
Auth7 & 0.26 & - & - & - & 0.29 \\
Auth8 & 0.65 & - & - & 0.65 & - \\
Auth9 & 0.63 & 0.70 & - & - & - \\
Auth10 & 0.55 & - & 0.55 & - & - \\
Auth11 & 0.50 & - & - & - & 0.49 \\
Auth12 & 0.68 & - & - & 0.71 & - \\
Auth13 & 0.54 & 0.58 & - & - & - \\
Auth14 & 0.60 & - & 0.61 & - & - \\
Auth15 & 0.68 & - & - & - & 0.67 \\
Auth16 & 0.65 & - & - & 0.65 & - \\
\hline
\end{tabular}


variable (authentic leadership) on its manifest variables. The parameters are significant $(p<0.05)$ if $t$-values are $\geq|1.96|$ (Diamantopoulos \& Siguaw, 2000). The $t$-values show that the four dimensions are significant indicators of the authentic leadership higher order factor, as the $t$-values are greater than 1.96. The results are shown in Table 5.

\section{Discriminant validity}

In this study, discriminant validity was assessed by comparing the average variance extracted (AVE) of each construct with the shared variance between constructs (Farrell, 2010). The AVE reflects the average proportion of variance in the indicator variables, which is accounted for by the latent variable relative to the variance because of measurement error (Diamantopoulos \& Siguaw, 2000). If the AVE for each construct is greater than its shared variance with any other construct, discriminant validity is supported. In this case, the shared variance estimates between the selfawareness subscale and the internalised moral perspective subscales were marginally greater than the AVE estimates for each of the constructs (Table 2). According to Diamantopoulos and Siguaw (2000), values less than 0.50 for the AVE indicate that measurement errors account for a greater proportion of the variance in the indicators so much so that the underlying variable itself raises some doubts about the soundness of the latent variable. In this case, the four AVE values are generally below 0.50 , thereby creating some doubts on the four latent variables.

\section{Power assessment}

Power assessment was conducted using the Rweb (1.03) translation of the Statistical Analysis System (SAS) syntax (Preacher \& Coffman, 2006). This syntax is used to derive the power estimates for the tests of exact and close fit. In the current study, the inputs for the analysis comprised a significance level of 0.05 , a sample size of 213 and 100 degrees of freedom (Table 6). A reasonably large power value of 0.9280824 for the test of exact fit was obtained. In this case, the authors rejected the null hypothesis of exact fit. The power of the test of close fit obtained was 0.9671278, which was high implying that, in the conditions that characterised this specific study, one would reject approximately $96.7 \%$ of incorrect models, thereby instilling some confidence in the model.

TABLE 5: Unstandardised gamma matrix.

\begin{tabular}{ll}
\hline Variable & $T$ \\
\hline Self-awareness & $7.67^{*}$ \\
Relational transparency & $7.00^{*}$ \\
Balanced processing & $9.61^{*}$ \\
Internalised moral perspective & $8.62^{*}$ \\
\hline
\end{tabular}

$*, p<0.05 ; t=t$-values; $t$-values $\geq|1.96|$ indicate significant parameter estimates.

TABLE 6: Power assessment for the structural model for the tests of exact and close fit.

\begin{tabular}{lccccc}
\hline Alpha & RMSEA (0) & RMSEA (a) & $\boldsymbol{N}$ & Power & df \\
\hline $\mathbf{0 . 0 5}$ & 0.00 & 0.05 & 213 & 0.9280824 & 100 \\
$\mathbf{0 . 0 5}$ & 0.05 & 0.08 & 213 & 0.9671278 & 100 \\
\hline
\end{tabular}

RMSEA, root mean square error of approximation; df, degrees of freedom; RMSEA (0), null hypothesis; RMSEA (a), alternative hypothesis.

\section{Discussion}

This study sought to assess the transportability of the ALI by Neider and Schriesheim (2011) by ascertaining its reliability and construct validity on a Nigerian sample.

\section{Summary of the research results}

The Cronbach's alpha values obtained indicate that the reliability coefficients for the four dimensions of the four ALI subscales indicate moderate reliability with two of the coefficients slightly below the 0.70 threshold and the other two coefficients marginally above the 0.70 threshold (Nunnally \& Bernstein, 1994). When treated as a unidimensional scale, the Cronbach's alpha coefficient was high $(\alpha=0.90)$. This is not completely in tandem with the high reliability coefficients obtained by Men and Stacks (2014), Neider and Schriesheim (2011) and Stander et al. (2015), although Van Der Vaart et al. (2015) in a South African study established satisfactory reliability estimates between 0.60 and 0.93. As a result of the limited number of ALI items, efforts to improve the reliability coefficients are not possible.

The four ALI subscales were found to be uni-dimensional and accounted for more than $50 \%$ of the variance with the exception of the internalised moral perspective subscale, which accounted for $44.4 \%$ of the variance. In terms of construct validity, the first- and second-order, bi-factor and singlefactor measurement models showed reasonable model fit to the data. The fit indices were, surprisingly, within the same range. In addition, the authors also tested for discriminant validity in which one of the shared variance estimates were marginally greater than the AVE estimates for each of the constructs raising some doubts on the discriminant validity of the self-awareness and the internalised moral perspective subscales. The AVE estimates obtained for the four ALI subscales were below 0.50 raising some doubts on the soundness of the indicators and/or the latent variables themselves (Diamantopoulos \& Siguaw, 2000).

\section{Limitations of the study and suggestions for future research}

Although the study was less skewed in terms of gender, the sample may not be representative of the Nigerian sample given that a non-probability sampling technique was used. This technique affects the generalisability of the findings. Future studies should replicate the study using bigger and culturally diverse samples.

More conclusive research on the psychometric properties of the ALI is required. Future studies should also determine the measurement equivalence and measurement invariance of the ALI across different Nigerian cultural groups.

\section{Conclusion}

The findings from the present study caution that using a more randomised sampling technique and the use of the 
ALI in leadership research in Nigeria should explore more diverse demographic variables in the population. However, given the original premise that necessitated the present investigation, it can safely be concluded that the ALI would be an adequate instrument, whose psychometric properties have somewhat been confirmed, for studying the construct of authentic leadership among a Nigerian research population.

\section{Acknowledgements}

Thank you to all those who made this study a success.

\section{Competing interests}

The authors declare that they have no financial or personal relationships that may have inappropriately influenced them in writing this article.

\section{Authors' contributions}

T.V.B. (University of Western Cape), the project leader, was responsible for data collection and article write-up - the project is based on her $\mathrm{PhD}$ dissertation; C.A.-I. was responsible for the article write-up; and B.M. was responsible for the article write-up and statistical analyses.

\section{Funding information}

This research received no specific grant from any funding agency in the public, commercial or not-for-profit sectors.

\section{Ethical consideration}

Permission from the university's research ethics committee was received.

\section{Data availability statement}

Data sharing is not applicable to this article as no new data were created or analysed in this study.

\section{Disclaimer}

The views and opinions expressed in this article are those of the authors and do not necessarily reflect the official policy or position of any affiliated agency of the authors.

\section{References}

Agote, L., Aramburu, N. \& Lines, R. (2016). Authentic leadership perception, trust in the 'leader, and followers' emotions in organizational change processes. Journal of Applied Behavioral Science, 52(1), 35-63. https://doi.org/10.1177/ 0021886315617531

Alok, K. (2014). Authentic leadership and psychological ownership: Investigation of interrelations. Leadership \& Organization Development Journal, 35(4), 266-285. https://doi.org/10.1108/LODJ-06-2012-0080

Alok, K., \& Israel, D. (2012). Authentic leadership \& work engagement. Indian Journal of Industrial Relations, 47(3), 498-510.

Amunkete, S., \& Rothmann, S. (2015). Authentic leadership, psychological capital, job satisfaction and intention to leave in state-owned enterprises. Journal of Psychology in Africa, 25(4), 271-281. https://doi.org/10.1080/14330237.2015.1078082

Avolio, B.J. (1999). Full leadership development: Building the vital forces in organizations. Thousand Oaks, CA: Sage.

Avolio, B.J., \& Gardner, W.L. (2005). Authentic leadership development: Getting to the root of positive forms of leadership. The Leadership Quarterly, 16(3), 315-338. https://doi.org/10.1016/j.leaqua.2005.03.001
Avolio, B.J., Gardner, W.L., Walumbwa, F., Luthans, F., \& May, D.R. (2004). Unlocking the mask: A look at the process by which authentic leaders impact follower the mask: A look at the process by which authentic leaders impact follower org/10.1016/j.leaqua.2004.09.003

Banks, G.C., McCauley, K.D., Gardner, W.L., \& Guler, C.E. (2016). A meta-analytic review of authentic and transformational leadership: A test for redundancy. Leadership Quarterly, 27(4), 634-652. https://doi.org/10.1016/j.leaqua.2016.02.006

Clapp-Smith, R., Vogelgesang, G.R., \& Avey, J.B. (2009). The mediating role of trust at the group level of analysis. Journal of Leadership \& Organizational Studies, 15(3), 227-240. https://doi.org/10.1177/1548051808326596

Covelli, B., \& Mason, I. (2017). Linking theory to practice: Authentic leadership. Academy of Strategic Management Journal, 16(3), 1-10.

Datta, B. (2015). Assessing the effectiveness of authentic leadership. International Journal of Leadership Studies, 9(1), 62-75.

Diamantopoulos, A., Siguaw, J.A., \& Siguaw, J.A. (2000). Introducing LISREL: A guide for the uninitiated. Thousand Oaks, CA: Sage.

Du Plessis, M. (2014). The relationship between authentic leadership, psychological capital, followership and work engagement. PhD dissertation, Cape Town: University of the Western Cape.

Du Toit, S., Du Toit, M., Mels, G., \& Cheng, Y. (2008). LISREL for windows: SIMPLIS syntax files. Scientific Software International. Retrieved from http://www. ssicentral.com

Eagly, A.H. (2005). Achieving relational authenticity in leadership: Does gender matter? Leadership Quarterly, 16(3), 459-474. https://doi.org/10.1016/j. leaqua.2005.03.007

Farrell, A.M. (2010). Insufficient discriminant validity: A comment on Bove, Pervan, Beatty, and Shiu (2009). Journal of Business Research, 63(3), 324-327. https://doi. org/10.1016/j.jbusres.2009.05.003

Gardner, W.L., Avolio, B.J., Luthans, F., May, D.R., \& Walumbwa, F. (2005). 'Can you see the real me?' A self-based model of authentic leader and follower development. The Leadership Quarterly, 16(3),343-372. https://doi.org/10.1016/j.leaqua.2005.03.003

Gardner, W.L., Cogliser, C.C., Davis, K.M., \& Dickens, M.P. (2011). Authentic leadership: A review of the literature and research agenda. The Leadership Quarterly, 22(6), 1120-1145. https://doi.org/10.1016/j.leaqua.2011.09.007

George, B. (2003). Authentic leadership. Rediscovering the secrets to creating lasting value. Jossey-Bass. Retrieved from https://www.wiley.com/en-us/Authentic+Leade rship\%3A+Rediscovering+the+Secrets+to+Creating+Lasting+Value-p-978078 7969134

George, B., \& Sims, P. (2007). True north: Discover your authentic leadership. JosseyBass. Retrieved from https://www.safaribooksonline.com/library/view/truenorth-discover/9780787987510/

George, B., Sims, P., McLean, A.N., \& Mayer, D. (2007, February). Discovering your authentic leadership. Harvard Business Review, 87(2), 129-138.

Goffee, R., \& Jones, G. (2005). Managing authenticity: The paradox of great leadership. Harvard Business Review, 87-94. Retrieved from http://web.a.ebscohost.com. ezproxy.uwc.ac.za/ehost/pdfviewer/pdfviewer?vid=1\&sid=58cfdc03-dd0f-4acfbe74-6c63598aa987\%40sessionmgr4005\&hid $=4209$

Hair, J.F., Black, W.C., Babin, B.J., \& Anderson, R.E. (2010). Multivariate data analysis A global perspective (7th edn.). Upper Saddle River, NJ: Pearson.

Harter, S. (2002). Authenticity. In C.R. Snyder \& S.J. Lopez (Eds.), Handbook of positive psychology (p. 382). London: Oxford University Press.

IBM Corporation. (2017). IBM SPSS statistics for windows, version 25.0. Armonk, NY: Author.

Ilies, R., Morgeson, F.P., \& Nahrgang, J.D. (2005). Authentic leadership and eudaemonic well-being: Understanding leader-follower outcomes. The Leadership Quarterly, 16(3), 373-394. https://doi.org/10.1016/j.leaqua.2005.03.002

Johnson, S.L. (2019). Authentic leadership theory and practical applications in nuclear medicine. Journal of Nuclear Medicine Technology, 47(3), 181-188. https://doi. org/10.2967/jnmt.118.222851

Jöreskog, K.G., \& Sörbom, D. (1996). PRELIS 2 user's reference guide: A program for multivariate data screening and data summarization: A preprocessor for LISREL. Mooresville, IN: Scientific Software.

Jöreskog, K.G., \& Sörbom, D. (2006a). An introduction to LISREL 8. 80 for Windows. Retrieved from www.ssicentral.com/lisrel/techdocs/Session1.pdf

Jöreskog, K.G., \& Sörbom, D. (2006b). LISREL for Windows (Version 8.80) [Computer Software]. Lincolnwood, IL: Scientific Software International. Retrieved from http://www.ssicentral.com/lisrel/references.html

Kark, R., \& Shamir, B. (2003). The dual effect of transformational leadership: Priming relational and collective selves and further effects on followers. In B. Avolio \& F. Yammarino (Eds.), Transformational and charismatic leadership: The road ahead, 2, (Vol.2, pp. 67-91).Oxford: Elsevier Science.

Klenke, K. (2007). Authentic leadership: A self, leader, and spiritual identity perspective. International Journal of Leadership Studies, 3(1), 68-97. https://doi. org/10.1016/j.leaqua.2007.03.003

Kotzé, M., \& Nel, P. (2019). Job and personal resources as mediators in the relationship between iron-ore mineworkers' job demands and work engagement. SA Journal of Human Resource Management/SA Tydskrif vir Menslikehulpbronbestuur, 17, a1183. https://doi.org/10.4102/sajhrm.v17i0.1183

Luthans, F., \& Avolio, B.J. (2003). Authentic leadership: A positive development approach. In K.S. Cameron, J.E. Dutton \& R.E. Quinn (Eds.), Positive organizational scholarship (pp. 241-261). Retrieved from https://scholar.google.co.za/scholar?h I=en\&q=Authentic+leadership $\% 3 \mathrm{~A}+\mathrm{a}+$ positive+developmental+approach\&btnG $=$ \&as_sdt=1\%2C5\&as_sdtp= 
Luthans, F., Avolio, B.J., Avey, J.B., \& Norman, S.M. (2007). Positive psychological capital: Measurement and relationship with performance and satisfaction. Personnel Psychology, 60, 541-572. https://doi.org/10.1111/j.1744-6570.2007.00083.x

McCain, J., \& Salter, M. (2004). Why courage matters: The Way to a Braver Life (1st edn.). New York: Random House.

Men, L.R., \& Stacks, D. (2014). The effects of authentic leadership on strategic internal communication and employee-organization relationships. Journal of Public Relation Research, 26(4), 301-324. https://doi.org/10.1080/1062726X.2014.908720

Müceldili, B., Turan, H., \& Erdil, O. (2013). The influence of authentic leadership on creativity and innovativeness. Procedia - Social and Behavioral Sciences, 99, 673-681. https://doi.org/10.1016/j.sbspro.2013.10.538

Munyaka, S.A., Boshoff, A.B., Pietersen, J., \& Snelgar, R. (2017). The relationships between authentic leadership, psychological capital, psychological climate, team commitment and intention to quit. SA Journal of Industrial Psychology, 43(1) 1-11. https://doi.org/10.4102/sajip.v43i0.1430

Neider, L.L., \& Schriesheim, C.A. (2011). The authentic leadership inventory (ALI) Development and empirical tests. Leadership Quarterly, 22(6), 1146-1164. https://doi.org/10.1016/j.leaqua.2011.09.008

Nel, P., \& Van Zyl, E. (2015). Assessing the psychometric properties of the revised and abbreviated self-leadership questionnaires. SA Journal of Human Resource Management/SA Tydskrif vir Menslikehulpbronbestuur, 13, 1-8. https://doi. org/10.4102/sajhrm.v13i1.661

Northouse, P.G. (2015). Leadership: Theory and practice (7th edn.). Los Angeles: Sage. Nunnally, J.C., \& Bernstein, I.H. (1994). Psychometric theory (3rd edn.). New York: McGraw-Hill.

Pallant, J. (2016). SPSS survival manual a step by step guide to data analysis using SPSS program (6th edn.). London: McGraw-Hill Education.

Preacher, K.J., \& Coffman, D.L. (2006). Computing power and minimum sample size for RMSEA [Computer software]. Retrieved from http://quantpsy.org

Roux, S. (2010). The relationship between authentic leadership, optimism, self-efficacy and work engagement: An exploratory study. Doctoral dissertation. Stellenbosch: University of Stellenbosch.

Rubin, D.B. (2004). Multiple imputation for nonresponse in surveys. New York: Wiley.

Ryan, R.M., \& Deci, E.L. (2003). On assimilating identities to the self: A selfdetermination theory perspective on internalization and integrity within cultures. In M.R. Leary \& J.P. Tangney (Eds.), Handbook of self and identity (pp. 253-272) New York: Guilford Press.
Schumacker, R.E., \& Lomax, R.G. (2016). A beginner's guide to structural equation modeling (4th edn.). New York: Routledge.

Shamir, B., \& Eilam, G. (2005). 'What's your story?' A life-stories approach to authentic leadership development. Leadership Quarterly, 16(3), 395-417. https://doi. org/10.1016/j.leaqua.2005.03.005

Stander, F.W., De Beer, L.T., \& Stander, M.W. (2015). Authentic leadership as a source of optimism, trust in the organization and work engagement in the public health care sector. SA Journal of Human Resource Management, 13(1), 1-13. https://doi. org/10.4102/sajhrm.v13i1.675

Tabachnick, B.G., \& Fidell, L.S. (2013). Using multivariate statistics (6th edn.). New York: Allyn \& Bacon/Pearson Education.

Terry, R.W. (1993). Authentic leadership: Courage in action (6th edn.). San Francisco, CA: Jossey-Bass.

Van Der Vaart, L., Stander, M., \& Rothmann, S. (2015). The validation of the authentic leadership inventory (ALI). In Unpublished manuscript, Optentia Research Focus Area (p. 6). Vanderbijlpark: North-West University. Retrieved from http://www.ianrothmann.com/download. php?conferenceid=37

Walumbwa, F., Avolio, B.J., \& Hartnell, C.A. (2010). An investigation of the relationships among leader and follower psychological capital, service climate and job performance. Personnel Psychology, 63, 937-963. https://doi.org/10.1111/ j.1744-6570.2010.01193.x

Walumbwa, F., Avolio, B.J., Gardner, W.L., Wernsing, T.S., \& Peterson, S.J. (2008). Authentic leadership: Development and validation of a theory-based measure. Journal of Management, 34(1), 89-126. https://doi.org/10.1177/0149206307308913

Walumbwa, F., Wang, P., Wang, H., Schaubroeck, J., \& Avolio, B.J. (2010). RETRACTED: Psychological processes linking authentic leadership to follower behaviours Leadership Quarterly, 21(5), 901-914. https://doi.org/10.1016/j.leaqua.2010. 07.015

Wang, D.-S., \& Hsieh, C.-C. (2013). The effect of authentic leadership on employee trust and employee engagement. Social Behaviour and Personality, 41(4), 613-624. https://doi.org/10.2224/sbp.2013.41.4.613

Wang, H., Sui, Y., Luthans, F., Wang, D., \& Wu, Y. (2014). Impact of authentic leadership on performance: Role of followers' positive psychological capital and relational processes. Journal of Organizational Behaviour, 35, 5-21. https://doi.org/10.1002/job

Yammarino, F.J., Dionne, S.D., Schriesheim, C.A., \& Dansereau, F. (2008). Authentic leadership and positive organizational behaviour: A meso, multi-level perspective. Leadership Quarterly, 19(6), 693-707. https://doi.org/10.1016/j.leaqua.2008. 09.004 